\title{
ПОСТРОЕНИЕ СЛОВАРЯ МАХМУДА КАШГАРИ «ДИВАН ЛУГАТ АТ-ТУРК》 (СРАВНИТЕЛЬНЫЙ АНАЛИЗ СЛОВАРЕЙ АЛЬ-ФАРАБИ «ДИВАН АЛЬ- АДАБ ФИ БАЯН ЛЮГАТИЛ-Л-АРАБ» И МАХМУДА КАШГАРИ «ДИВАН ЛУГАТ-АТ-ТУРК»)
}

\author{
Гейдарова Хадиджа Исабала гызы \\ канд. филол. наук, старший научный сотрудник, \\ Институт языкознания им. Насими, Наџиональная Академия наук Азербайджана
}

DOI: https://doi.org/10.31435/rsglobal_wos/28022020/6916

\section{ARTICLE INFO}

Received: 14 December 2019

Accepted: 19 February 2020

Published: 28 February 2020

\section{KEYWORDS}

dictionary,

verb,

noun,

lexicographer,

babes,

abnias,

rhyme method.

ABSTRACT

The famous Uyghur linguist and lexicographer of the 11th century, Mahmoud Kashgari, in the preface to the dictionary "Divan Lugat-atTurk", although he cites the name of the dictionary of the 8th-century Arabic lexicographer Khalil bin Ahmed "Kitab al-Ain", did not use it in terms of building the dictionary. In fact, Kashgari does not provide any information about the principles of constructing which dictionary served as an example for him. Many researchers believe that the dictionary by Abu Ibrahim Ishaq ibn Ibrahim al-Farabi "Divan al-adab fi bayan lugatil-arab" is a prototype of the "Divan" by Kashgar. The article discusses similar and distinctive features of these two dictionaries. The article also speaks of the qafiya rhyme method, in Arabic lexicography associated with the name Ismail al-Jawhari, first used in reality in the al-Farabi dictionary "Divan al-adab", although in a primitive form.
\end{abstract}

Citation: Гейдарова Хадиджа Исабала гызы. (2020) The Construction of the Dictionary by Mahmud Kashgari "Divan Lugat At-Turk" (a Comparative Analysis of the Dictionaries by Al-Farabi "Divan Al-Adab Fi Bayan Lugatil-1-Arab" and Mahmud Kashgari "Divan Lugat At-Turk"). International Academy Journal Web of Scholar. 2(44). doi: 10.31435/rsglobal_wos/28022020/6916

Copyright: (C) 2020 Гейдарова Хадиджа Исабала гызы. This is an open-access article distributed under the terms of the Creative Commons Attribution License (CC BY). The use, distribution or reproduction in other forums is permitted, provided the original author(s) or licensor are credited and that the original publication in this journal is cited, in accordance with accepted academic practice. No use, distribution or reproduction is permitted which does not comply with these terms.

Представитель исламского мира X века учёный-языковед и лексикограф Абу Ибрахим Исхак ибн Ибрахим аль-Фараби (872-961 гг. по миладу) родом был из местности Фараб (город Отрар), находящейся в Южном Казахстане. Он был земляком и современником философа Абу Насра Мухаммеда ибн Мухаммеда Фараби (870-950). Аль-Фараби был дядей и одновременно учителем аль-Джаухари, являющимся одним из знаменитых представителей арабской лексикографии. Метод «рифмы», связанный с именем аль-Джаухари в арабской лексикографии, в действительности был впервые применен, хотя и в примитивной форме в словаре «Диван-альАдаб» аль-Фараби, но поскольку сложные структурные абнии и бабы, имеющиеся в его составлении, затрудняли использование словаря, этот словарь не был включен в классификацию арабских лексикографических школ. Его произведение на протяжении многих веков оставалось без внимания, лишь после того, как выяснилось, что этот словарь является прототипом словаря «Диван Лугат-ат-Турк» Махмуда Кашгари, он привлек внимание некоторых исследователей. В XX веке словарь аль-Фараби был издан два раза: первое издание под названием «Диван аль-Адаб фи-л-Луга» - в 1970 году. А во второй раз - в годы Второй мировой войны, после того как рукопись словаря была случайно обнаружена египетскими учеными в Александрийской библиотеке, после проведения долгих исследований наконец-то была напечатана в 1974-1984 годах в четырех томах. Работы аль-Фараби были привлечены 
немецким востоковедом К.Броккельманом к расширенным исследованиям. Аль-Фараби отказался от популярного в тот период метода Халила, но применил систему абнии (распределение лексических групп по числу букв). В отличие от Халила Фараби провел раздел классификации лексичекого материала по глаголам, неопределенной форме глагола, фаилам и мафулам. И поэтому первый опыт подачи парадигматических моделей в иерархической последовательности (абния - расклад) относится к словарю аль-Фараби «Диван-аль-Адаб». Он разделил свое произведение на шесть книг и расположил книги в зависимости от особенностей арабских букв и количества согласных в корнях слов в нижеприведённой последовательности:

I книга «Салим» (слова, в составе которых нет букв алиф, вав, однако в составе которых могли присутствовать хамза и двойные буквы);

II книга «Мудааф» (слова с двойными согласными);

III книга «Пример» (в составе алиф, вав или одной из букв);

IV книга «Завату-с-саласа» (трехсогласные корни);

V книга «Завату-л-арбаа» (четырёхсогласные корни);

VI книга «Хамза» (корни с хамзой) [6. الأب ديوان بمجم مختصر تعريف].

Каждая книга делится на две части: имена существительные и глаголы. Как сам он отмечал, имена существительные ставились перед глаголами [Рыбалкин, 1984, с. 60]. В.С. Рыбалкин описывает «порядок изложения именных форм, куда попадают и некоторые масдары, в аспекте муджаррад/мазид реализован следующим образом: а) трехбуквенные первообразные модели /ас-суласи, ал-муджаррад/, типа: «инаб»; б) трехбуквенные модели с префиксом алиф или мим, типа: 'исба', мазхаб; в) трехбуквенные модели с "отягощенной" /мусаккал/, типа: химмас; г) трехбуквенные модели с инфиксом; д) то же между $\mathrm{K}_{2}$ и $\mathrm{K}_{3}$, типа: сахаб; е) трехбуквенные модели с постфиксом, типа: хидабб; ж) четырехбуквенные модели и те, что к ним примыкают, типа: са'лаб'; з) пятибуквенные модели и те, что к ним примыкают, типа: джирдахл» [Рыбалкин, 1984, с.61].

По мере углубления в обширную и разветвленную парадигматику имен, четкость принципов группировки их отдельных моделей в главы для аль-Фараби выдерживать все труднее; принципы эти становятся все более размытыми, а некоторые из моделей начинают входить в отдельные главы в единственном числе. Впрочем, и количество слов, которые аль-Фараби отыскивает на ту или иную парадигму порой ограничивается единицами. [Рыбалкин, 1984, с.63]. Следует отметить, что арабские переводческие словари XI-XIII веков были больше учебными пособиями по изучению языка, чем словарями. Здесь очень выпукло применялись грамматическая классификация, фонетическое деление и пояснения. Это привело к тому, что основные функции словаря отошли на задний план. Одна из ключевых функций словаря состоит в том, чтобы сделать его простым в использовании, чтобы пользователь для нахождения нужного слова не ломал голову над морфологическим, фонетическим и орфографическим строением слова и не задавался вопросом «в какой книге это может быть?» Чтобы найти слово в словаре аль-Фараби, требуется глубокая филологическая грамотность. Как отмечалось выше, впервые в арабской лексикографии Фараби применил метод рифмы. Он применил это к согласным и к гласным. Так, в расположении словника словаря сначала даются корни с фатхой (звук а), затем следуют с даммой (звук у), а затем уже следуют корни с кясрой (звук и). Корни, начинающиеся с буквы bə (ب) и внешне слабыми согласными (алиф, вав, йа), составлены в алфавитном порядке. Основное различие между словарем аль-Фараби и словарем «Китаб Аль-Айн» основателя арабского словаря Халила ибн Ахмеда заключается в этом [6. الأدب ديوان بمعم مختصر تعريف]. В предисловии к словарю Фараби пишет: «Мы начинали словами, корни которых даются с фатхой. Потому что это самое удобное среди хараков (отметка гласных звуков, не отображаемых буквами на письме), оно выходит из полости рта без всякого напряжения, легко произносится. За ними следуют корни с даммой, затем идут с кясрой. В корне, которых имеется сукун, мы расположили до фатхы, потому что сукун самый легкий среди хараков». Значит, согласно аль-Фараби, ранжирование основано на фонетическом принципе $\stackrel{\rightarrow}{\rightarrow} \rightarrow$ [ЗЗариназаде, 1974, с. 184]. Основную особенность метода рифмы аль-Фараби объяснил таким образом: «Мы начинаем с корней имён существительных, заканчивающихся на букву ба (ب), и таким образом продолжаем в алфавитном порядке, пока алфавит не заканчивается, мы не включаем «слабые» (в составе которых имеется одна из букв алфавита алиф (I), вав (و), йа (ي)). Тем самым мы не идем по пути Халила ибн Ахмеда, применяем знакомый всем алфавитный ряд. Корни, в которых последняя буква совпадает, сортируются по 
первой букве в алфавитном порядке. Если первые буквы слов одни и те же, то в алфавитном ряду по второй букве ставится слово» [Рыбалкин, 1984, с. 60-61].

Порядок слов в соответствии с последней буквой и второй буквой является одним из основных условий метода рифмы и впервые был применен аль-Фараби. Однако повторный принцип внесения заново по алфавитному порядку слов по последней и второй букве слова многочисленных парадигматических разделов, излишних для словарного дела, в действительности исходящий из этой школы, отстает от метода составления Аль-Джаухари, потому что он внедрил единую алфавитную систему в макросистему словаря «Ас-Сыхах». Как и аль-Фараби в названии словаря Кашгари также использовал слово «диван» (запись), потому что в словаре было дано место для обширного иллюстративного материала; при сравнении заголовков разделов двух словарей наблюдается одинаковая структура. Разница в том, что Кашгари разделил свой словарь на восемь книг, главу «Хамза» сделал первой книгой, нехарактерные для арабского языка слова (состоящие из носовых звуков) поместил в своей седьмой книге, названной «Гюннели слова», в восьмую книгу вошли слова со сукун с удвоенными согласными. Другие главы, находящиеся в середине, были расположены в последовательности, данной, как и в словаре Фараби. В бабах, заканчивающихся словами с одинаковыми буквами, согласные постоянные, только меняются гласные, например: арк, орк, ирк. Расположение слов в словнике словаря по последней букве слова арабского алфавита, соответственно, является основным методом составления словника. Как и в словаре альФараби, за этими словами, первая буква которых одинаковая, происходит изменение по второй букве: ирк, илк. В «Диване» Кашгари каждая парадигматическая часть начинается с нового алфавитного порядка. Следует отметить, что в этом вопросе, говоря буква, понимается согласная, говоря хамза и харака, должна пониматься гласная буква.

Таким образом, словарь Кашгари состоит из следующих книг: 1) Книга «Хамза» (كتاب

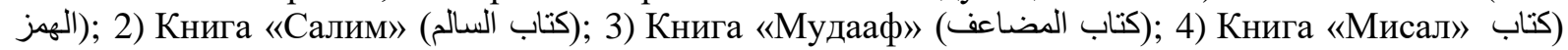

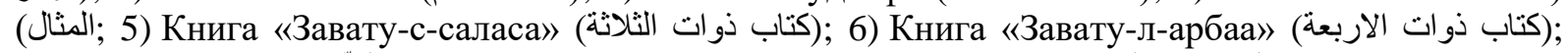
7) Книга «Гюнна» (كتاب الغّة)

Во всех книгах словаря все главы и бабы составлены по единому принципу. Как и альФараби, Кашгари разделил свои книги на имена существительные и глаголы. Во вступительном слове к словарю он отмечает, что имена существительные даются перед глаголами. Каждое из них слово по количеству согласных букв в корне делятся на бабы (количество букв может варьироваться от пяти до семи), бабы делятся на мудаафы (двойные согласные), мисалыпримеры (слова, начинающиеся с буквы уә), мангус (слова, одна из букв которых əlif, vav, уə), гюнне (слова со звуком [nq]), слова, в середине которых сукуны, матви (слова, в составе которых буквы əlif, vav, уə) и так далее. В книгах, связанных с глаголами, Кашгари приводит временные аффиксы и неопределённые формы глаголов и дает подробные и краткие грамматические объяснения. Хотя заголовки, данные в словаре, являются повторением терминов арабского языкознания, в целом, названия книг и словник были определены Кашгари в соответствии с фонетической и морфологической системой тюркского языка. Тем не менее, разделение бабов никогда не было одинаковым, неопределённым в единой системе, в индивидуальном порядке были разделены на заголовки. Невозможно определить макросистему словаря из-за многочисленного ненужного парадигматического расщепления, если глубоко задуматься, по причине обновления в каждой классификации алфавитного порядка по последней букве и второй букве слова. Как и в словаре аль-Фараби, многочисленные парадигматические модели распределения в произведении Кашгари иногда должны ограничиваться одним или двумя примерами. В результате мы можем сказать, что в словаре Кашгари невозможно определить единую макросистему словаря из-за того, что в одной и той же системе не обнаруживаются деления бабов, индивидуально выделяются заголовки, множественное ненужное парадигматическое разбиение и в каждой классификации обновляется алфавитный ряд по последней букве и второй букве корня слова. Хотя метод рифмы, созданный аль-Фараби, в действительности является успешным открытием для арабской лексикографии, в системе абнии в разделах баб наблюдаются ненужные бесчисленные фрагменты, что является неприемлемым в словарном деле. К сожалению, это неудачное сложное строение словаря «Диван аль-Адаб» Исхака аль-Фараби повторилось и в словаре Кашгари. Так, чтобы найти тюркское слово в произведении «Диван Лугат-ат-Турк», которое является тюркско-арабским словарем, сначала пользователь должен был хорошо знать 
морфологию и фонетику арабского и тюркского языка, его орфографию на основе арабского алфавита, а главное, также, как и Кашгари. Естественно, в тот период никто не мог бы пользоваться с успехом этим словарём, за исключением тех языковедов, кто знал бы тюркский язык на филологическом уровне. Наверное, по этой причине произведение «Диван Лугат-атТурк» не смогло завоевать в свое время широкую популярность, доказательством чего является то, что его не часто переписывали и отсутствие его последователей.

Хотя словник, иллюстративные и грамматические материалы, сравнительные исследования тюркских языков и, наконец, многочисленные парадигматические распределения являются бесценным филологически-лексикографическим материалом для более позднего периода тысячелетия, структура словаря, к сожалению, не может считаться удачной с точки зрения пользователя.

\section{ЛИТЕРАТУРА}

1. Dîvânü Lugati't-Türk. Tıpkıbasım. "Faksimile". - Ankara: Alaeddin Kirsi Basımevi, 1941. - 638 səh.

2. Mahmud Kaşğari. Divanü lüğat-it-türk. Ramiz Đskərin tərcüməsi. Dörd cilddə. 4 cilddə, Bakı, "Ozan”, 2006.

3. Zərinəzadə H. H. Orəbcə-azərbaycanca lüğətin nəzəri əsasları (filologiya elmləri doktoru alimlik dərəcəsi almaq üçün təqdim edilmiş dissertasiya), Bakı, 1974, 304 səh.

4. Рыбалкин В.С. Принципы построения арабских лексикографических трудов VIII-XVIII вв.: Диссертация на соискание учёной степени кандидата филологических наук. Ленинград, 1984. 229 c.

5. محد الكثغاري . كتاب ديو ان لغات الترك. 322سنة هجرية.

6. 